
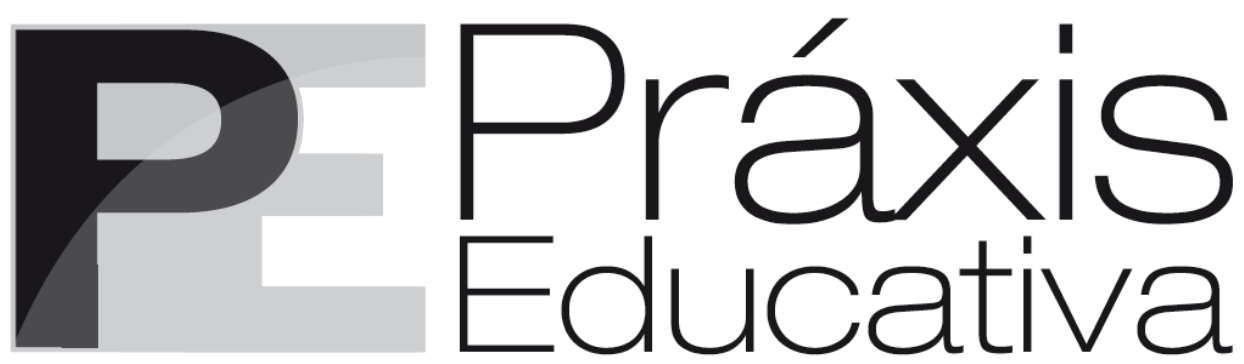

ISSN 1809-4309 (Versão online)

DOI: 10.5212/PraxEduc.v.12i3.003

\title{
Gestão privada de escolas públicas da Educação Básica: um novo mercado sob a tutela do Estado
}

\section{Private management of public schools of Basic Education: a new market under the auspices of the State}

\section{Gestión privada de las escuelas públicas de la Educación Básica: un nuevo mercado bajo la autoridad del Estado}

\author{
Bruno Gawryszewski* \\ Vânia Cardoso da Motta* \\ Camila Kipper Putzke
}

Resumo: Este artigo discute a gestão privada de escolas públicas da Educação Básica como um dos pilares que sustentam uma agenda privada-mercantil no cenário contemporâneo brasileiro, baseados na crença da maior eficiência e qualidade a fim de garantir a igualdade de oportunidade a todos. O recurso teóricometodológico foi a análise da atual conjuntura brasileira inserida na crise estrutural do capital, seguida de exame da gestão privada em escolas estadunidenses, conhecidas como escolas charters, e iniciativas nas redes de ensino no Brasil. Concluímos que a gestão privada de escolas públicas pode ser entendida como um recurso para "contrarrestar" as crises cíclicas do capital e que tem aberto novas possibilidades de mercado no âmbito educacional sob a tutela do Estado.

Palavras-chave: Estado. Gestão privada. Crise do capital.

Abstract: This paper aims to present the private management of public schools of Basic Education as one of the pillars that support a private-market agenda in the Brazilian contemporary field, based on the belief of greater efficiency and quality in order to ensure equal opportunity to all. The theoretical and methodological approach was the analysis of the current Brazilian situation included in the structural crisis of the capital, followed by the examination of private management in American schools, known as charter schools, and initiatives for the education networks in Brazil. We conclude by stating that the private management of public

\footnotetext{
* Professor da Faculdade de Educação da Universidade Federal do Rio de Janeiro (UFRJ), integrante do Coletivo de Estudos em Marxismo e Educação (COLEMARX). E-mail: <brunogawry@gmail.com>.

** Professora da Faculdade de Educação da Universidade Federal do Rio de Janeiro (UFRJ), integrante do Coletivo de Estudos em Marxismo e Educação (COLEMARX). E-mail: <vaniacmotta@gmail.com>.

*** Graduanda em Pedagogia pela Universidade Federal do Rio de Janeiro (UFRJ), integrante do Coletivo de Estudos em Marxismo e Educação (COLEMARX). E-mail: <camilaputzke@hotmail.com>.
}

Práxis Educativa, Ponta Grossa, v. 12, n. 3, p. 728-748, set./dez. 2017 Disponível em: < http://www.revistas2.uepg.br/index.php/praxiseducativa > 
schools can be seen as a resource to prevent the cyclical crises of capital, which has opened up new market opportunities in the education field under the auspices of the Brazilian state.

Keywords: State. Private management. Capital crisis.

Resumen: En este artículo se analiza la gestión privada de las escuelas públicas de Educación Básica como uno de los pilares que sostienen una agenda privado-mercantil en el entorno contemporáneo brasileño, basado en la creencia de una mayor eficiencia y calidad con el fin de garantizar la igualdad de oportunidades para todos. El enfoque teórico y metodológico fue el análisis de la situación actual de Brasil en la crisis estructural del capital, seguido de un examen de la gestión privada en las escuelas de Estados Unidos, conocidas como escuelas charter e iniciativas en las redes de educación en Brasil. Llegamos a la conclusión de que la gestión privada de escuelas públicas puede ser entendida como un recurso para hacer frente a las crisis cíclicas del capital y que ha abierto nuevas oportunidades de mercado en el sector de la educación bajo los auspicios del Estado.

Palabras clave: Estado. Gestión privada. Crisis de capital.

\section{Introdução}

O propósito do presente texto é pôr em tela a pauta da agenda privada-mercantil ${ }^{1}$, que tem como um de seus mais promissores vértices a gestão privada de escolas públicas da Educação Básica, difundida como solução para oportunizar uma educação com igualdade de oportunidades para todos, baseada na crença da "evidente" maior eficiência e "qualidade" da gestão privada sobre a pública. Trata-se de uma proposta que se espelha nas chamadas escolas charters estadunidenses, que estabeleceu a gestão privada nas escolas públicas por meio de organizações privadas (com ou sem fins lucrativos). Objetivamos evidenciar que essa proposta surge em um momento de crise do capital e que abre novas possibilidades de mercado sob a tutela do Estado.

No Brasil, esse modelo de escola já é uma realidade em algumas escolas das redes públicas de ensino estaduais e municipais, e já há indícios de estabelecer-se essa relação de gestão privada em toda uma rede de ensino. Dois fatos centrais conferem essa nova mediação histórica - as organizações sociais de direito privado gerindo o setor educacional público: i) no âmbito econômico, estrutural, o contexto de crise do capital em que, desde os anos 1970, as forças produtivas e políticas dominantes tentam reestabelecer a dinâmica de acumulação do capital mediante medidas austeras que incidiram na flexibilização e até supressão de direitos trabalhistas e na restrição de gastos públicos na esfera social; ii) no âmbito político e ideológico, superestrutural, as forças produtivas e políticas dominantes buscam lidar com os impasses políticos provocados pela classe dominada frente ao desemprego estrutural, ao aumento da pobreza e da desigualdade e o cerceamento dos direitos sociais, encaminhando políticas voltadas para amenizá-los. Entre elas, o Pacto Global, ${ }^{2}$ anunciado no

\footnotetext{
${ }^{1}$ Definimos como "agenda privada-mercantil” o conjunto de proposições de grupos sociais empresariais para atuarem no âmbito dos encaminhamentos de políticas públicas da Educação Básica, seja como "filantrocapitalistas", que "doam” o ethos empresarial para obter-se maiores resultados no desempenho escolar e alçar a suposta "igualdade de oportunidades", ou como forma de ampliar a acumulação do capital por meio de recursos públicos.

2 O "Pacto Global" objetivou formar uma rede constituída de vários setores da sociedade (governos, empresários, organizações não-governamentais, sindicatos e academia), em prol da harmonização do sistema. Neste, os empresários são vistos como protagonistas centrais na adoção de políticas de responsabilidade social e sustentabilidade, tendo em vista o desenvolvimento de um mercado global mais inclusivo e sustentável e constituir uma dimensão social à acumulação do capital.
}

Práxis Educativa, Ponta Grossa, v. 12, n. 3, p. 728-748, set./dez. 2017 Disponível em: <http://www.revistas2.uepg.br/index.php/praxiseducativa > 
Fórum Econômico Mundial, Davos, em 1999, e lançado pela Organização das Nações Unidas (ONU), em 2000, em Nova Iorque (MOTTA, 2012), que clamou pela atuação dos empresários para colaborar com a administração das mazelas sociais; e, mais especificamente no Brasil, a Reforma Administrativa do Aparelho do Estado (BRASIL, 1995), que introduziu a concepção de "público não-estatal” e regulamentou as organizações sociais de direito privado e de caráter público. ${ }^{3}$

$\mathrm{Na}$ perspectiva de que essas novas mediações históricas inserem uma política de Estado, o nosso ponto de partida para pensar a conjuntura brasileira não serão as políticas de governo, mas as relações de forças entre as classes fundantes, evidenciando a categoria da totalidade marxiana ${ }^{4}$. Hodiernamente, essas relações de forças incidem em uma conjuntura de crise estrutural do capital que, depois de ter atingido o auge da depressão nos países centrais do capitalismo global no final da década passada, reverbera com voracidade seu ciclo recessivo no Brasil, tornando visíveis as contradições inerentes do sistema do capital.

As medidas de ajuste fiscal e a "reforma" do Estado brasileiro - implementadas no governo de Fernando Henrique Cardoso (FHC) - atravessaram o governo de Luiz Inácio Lula da Silva, embora com benefícios de políticas sociais focadas e compensatórias ampliadas. No final do governo Dilma Rousseff, elas foram restauradas em seu caráter mais austero, com novos cortes no orçamento público, e têm ganhado impulso mais acelerado no atual governo Temer. Assim sendo, considerando as dimensões das crises, econômica e política, essas medidas sempre favoreceram a agenda privadamercantil. E a crise em que a sociedade brasileira está enredada no tempo presente fortalece a concretização e a consolidação dessa agenda.

No âmbito da Educação, especificamente sobre a questão da gestão privada de escolas públicas, consideramos que a pauta privada-mercantil já tomou uma dimensão pública, pelo menos desde a década passada, com iniciativas em caráter experimental, conforme discutiremos adiante. Por isso, para além das iniciativas de gestão privada nas redes públicas de ensino já realizadas no país, pretendemos conferir destaque às recentes tentativas dos governos estaduais de Goiás e Mato Grosso em privatizar parte de sua rede de ensino, justamente nesse contexto de crise do capital.

A fim de obtermos êxito no propósito enunciado, organizamos o texto nas seguintes seções: (1) O capital, suas crises e a conjuntura brasileira; (2) Escolas charters estadunidenses; (3) Escolas brasileiras de gestão privada; seguida das considerações finais.

\footnotetext{
3 Emenda Constitucional $n^{\circ}$ 19, de 1998, implementou modificações no regime administrativo brasileiro, a partir da alteração de um grande número de dispositivos da Constituição Federal de 1988, referentes tanto ao funcionamento da administração pública quanto às normas até então vigentes para os seus servidores. Tais modificações tiveram como pontos principais: a revisão das regras de estabilidade, a modificação no regime de remuneração e a gestão da administração pública. Programa Nacional de Publicização, que autoriza o Poder Executivo a, por meio da qualificação de entidades privadas como "organizações sociais", transferir-lhes a gestão de bens e serviços públicos a cargos de entidades autárquicas e fundacionais. Lei n. 9.637, de 15 de maio de 1998 (ADRIÃO; BEZERRA, 2013).

${ }^{4}$ Sobre a totalidade marxiana, Ciavatta (2001, p. 132) contribui que "[...] a totalidade é um conjunto de fatos articulados ou o contexto de um objeto com suas múltiplas relações, ou, ainda, um todo estruturado que se desenvolve e se cria como produção social do homem”.
}

Práxis Educativa, Ponta Grossa, v. 12, n. 3, p. 728-748, set./dez. 2017 Disponível em: <http://www.revistas2.uepg.br/index.php/praxiseducativa > 


\section{O capital, suas crises e a conjuntura brasileira}

Entendemos ser necessário explicitar pelo menos alguns parâmetros centrais do que poderíamos genericamente chamar de pressupostos de funcionamento do capital visando a compreensão de "crise do capital". Nesse sentido, é importante insistir que o capital não se trata de uma entidade material ou um indivíduo que se move guiado por interesses particulares, mas sim uma determinada relação social em um processo produtivo que se caracteriza por uma estrutura de controle que é apropriada, privadamente, por capitalistas. A classe capitalista, detendo o poder econômico e a capacidade de impor suas decisões, cinde a estrutura social em classes antagônicas em seu lugar na produção, favorecendo a divisão social hierárquica do trabalho e apropriação desigual da riqueza produzida.

Mészáros (2002, p. 100) sintetizou que a determinação mais profunda do sistema do capital é que este está “[...] orientado para a expansão e movido pela acumulação". Esse sistema de controle sociometabólico, conceituado pelo autor húngaro, tem um modo de funcionamento que, operado pelas personificações capitalistas, se ampara em impulso voraz para extrair trabalho excedente dos trabalhadores e transformar esse excedente em capital a ser empregado na reprodução expansionista para acumular mais capital. Trata-se, portanto, de um sistema que organiza estruturas produtivas para encontrar recursos e saídas para a expansão e a acumulação.

A partir dessas formulações, não faria sentido, no âmbito do domínio do sistema do capital, advogar por um capitalismo "autossustentado", pois tal prerrogativa afrontar-se-ia com o seu princípio fundante de expansão e acumulação. Assim, o pressuposto do capital em reproduzir e realizar valor torna imperativa a necessidade de que haja um avanço sobre a esfera da circulação, a fim de formar uma estrutura sólida entre a produção de mercadorias e seu respectivo consumo.

Nesses termos, o princípio constitutivo do sistema capital de permanente expansão e acumulação é definido por Mészáros (2002) como irrestringibilidade, pois, enquanto se encontra recursos e saídas para evitar-se a interrupção desse fluxo, as coisas seguem seu fluxo "natural". No entanto, a dinâmica contraditória do próprio capital faz com que, em determinados momentos, essa realização de valor não ocorra. Os motivos (diversos e combinados, por sinal) podem dar-se por conta da própria anarquia da produção que inunda o mercado com mercadorias que não são consumidas, resultando na queda na taxa de lucratividade ou na não realização do capital; o que genericamente são difundidas como crises. As crises instalam-se quando, segundo Mészáros:

[...] a ordem estabelecida de reprodução socioeconômica colide com obstáculos criados por sua própria articulação dualista, de modo que a tríplice contradição entre produção e controle, produção e consumo e produção e circulação já não pode mais ser conciliada, muito menos usada como maquinário poderoso do processo vital de expansão e acumulação. (MÉSZÁROS, 2002, p. 122).

Nos momentos de crise do capital, em que o processo de expansão e acumulação esteja se realizando sob dificuldade ou, em momentos extremos, até paralisado, a agenda que costumeiramente tende a ser defendida pelos próprios capitalistas (e não tem sido diferente nos dias atuais) passa pela necessidade de conferir condições objetivas para que se implemente mais capitalismo, de modo a tornar o cenário econômico mais "seguro" para investimentos internacionais. Para tal, defendem-se medidas que impliquem na redução dos custos produtivos, o que denota: rebaixar o valor da força de trabalho, desregulamentar ou flexibilizar legislações que constrangem a exploração dos recursos naturais e da força de trabalho, reduzir a cobrança de impostos pelo Estado,

Práxis Educativa, Ponta Grossa, v. 12, n. 3, p. 728-748, set./dez. 2017 Disponível em: <http://www.revistas2.uepg.br/index.php/praxiseducativa $>$ 
dentre outras, que, ao fim das contas, convergem para que o peso da crise capitalista recaia sobre a classe trabalhadora. Podemos dizer, portanto, que existe uma gestão das crises do capital e nela mecanismos que impedem a ascensão de movimentos de resistência organizados pelos trabalhadores.

Tendo em vista que o capital faz parte de um processo em que a forma dinheiro é impelida a continuamente produzir mais dinheiro, Harvey (2011), em um exercício retórico, indaga: "Por que os capitalistas reinvestem na expansão, em vez de consumir seus lucros em prazeres?" (HARVEY, 2011, p. 43). A essa pergunta, a resposta reside no modo de produção capitalista estruturar-se pela reprodução ampliada, de modo que parte do lucro se destina a ampliar sua escala de produção de mercadorias, no intuito de vencer a concorrência de outros capitalistas.

No entanto, Harvey (2011, p. 43) destaca que: "[O dinheiro] é uma forma de poder social que não tem limites inerentes". Logo, para ser reproduzido e ampliado, é necessário trucidar qualquer tipo de barreira que venha a limitar esse processo, de modo a encontrar possibilidades de investimento, o que o autor denomina como resolver "[...] o problema da absorção de excedentes de capital" (HARVEY, 2011, p. 45). Ou seja, capital represado não reproduz valor, logo não se realiza.

Se é consensual que o capitalismo já passou por diversas crises desde o século XIX, é possível observar que, em vários momentos do século XX, em especial na década de 1970, o capitalismo global tem sofrido intensos e constantes períodos de flutuação na estabilidade dos seus ganhos. No entanto, embora em uma perspectiva de longo prazo tenha ocorrido uma tendência declinante da taxa média de lucro, Alves (2013) chama a atenção de que o aspecto fundamental que tem marcado as crises estruturais do capital tem sido a "[...] crise de valorização produtiva (produção/realização) do valor” (ALVES, 2013, p. 35). Partindo dessa premissa, na qual nos apoiamos, a origem do problema não está na ausência de formação de valor, mas que esse valor formado e acumulado não encontra destino para se realizar, o que termina por dialogar com o pressuposto de Harvey de que tem ocorrido uma dificuldade na absorção de excedentes de capital.

Entretanto, conforme já destacamos anteriormente, o capital maneja estratégias de gestão de suas próprias crises no intuito de impedir o colapso do próprio sistema. Por conta dos limites e do escopo deste texto, não será possível desenvolver a contento acerca da discussão, mas vale mencionar que esse movimento de "contratendências" da queda da taxa média de lucro recorrentemente se ampara, dentre outras formas, na abertura de novos mercados, visando criar demanda para escoamento das mercadorias e do próprio capital. Assim, a expansão do comércio em nível global, os acordos de livre comércio, a realização de megaeventos, a privatização de empresas estatais e a própria constituição de blocos e de organizações econômicas, como a Organização para a Cooperação e Desenvolvimento Econômico (OCDE) e a Organização Mundial do Comércio $(\mathrm{OMC})^{5}$, são movimentos "contratendenciais" que atuam no intuito de aliviar o problema da "sobreacumulação". A esses mecanismos engendrados pelo capital sob os auspícios de seus representantes na esfera estatal é o que Harvey (2005) denominou como acumulação por espoliação.

\footnotetext{
5 Os países-membros da OMC assinaram, em 1995, o Acordo Geral sobre Comércio de Serviços (GATS - em sua sigla em inglês), tendo como objetivo a liberalização progressiva dos serviços no prazo de dez anos, incluindo a educação. Diante das dificuldades para concluir as negociações, o GATS não foi concluído e substituído por acordos bilaterais. No entanto, desde 2012, negocia-se em sigilo um novo tratado denominado TiSA (Acordo sobre o Comércio de Serviços em português). E a OCDE criou o Programa Internacional de Avaliação de Alunos (PISA), mecanismo que vem guiando as avaliações em larga escala de vários países.
}

Práxis Educativa, Ponta Grossa, v. 12, n. 3, p. 728-748, set./dez. 2017 Disponível em: <http://www.revistas2.uepg.br/index.php/praxiseducativa $>$ 
A tentativa de Harvey (2005) é de atualizar a categoria marxista da acumulação primitiva, que se manifestava por meio da privatização da terra, da expulsão violenta dos camponeses, da escravidão e da usura. Diferentemente da acumulação primitiva, a acumulação por espoliação, entendida como uma relação de dominação, não se vale exclusivamente de ações coercitivas. No estágio mais avançado do capitalismo e com uma sociedade civil mais complexa, organizada, procura-se combinar elementos de consenso, utilizando-se de mecanismos de cooptação ou de convencimento, para legitimar a apropriação privada dos ativos extraídos da riqueza socialmente produzida. Por isso, compreendemos que a acumulação por espoliação é uma condição determinante para que o capital se aposse e libere um conjunto de ativos ainda não introduzidos no circuito de reprodução econômica.

A acumulação por espoliação interfere positivamente no problema dos excedentes de capital, pois encontra destinos para sua realização lucrativa. Nesse sentido, o Estado desempenha um papel imprescindível, na medida em que intervém para regular os salários, coordenar a liberação de ativos, como as privatizações de empresas públicas e os tratados de livre comércio, e, ainda, tem o poder de orquestrar desvalorizações para permitir que a acumulação ocorra sem desencadear um colapso geral, propiciando o cenário perfeito para a concretização sua missão "salvacionista" em resgatar setores inteiros da economia. ${ }^{6}$

Pode-se sintetizar as funções do Estado em ajustar as "imperfeições" do sistema do capital em ações estruturais como o de fornecer uma estrutura jurídica que assente as relações sociais estabelecidas; ajustar suas funções reguladoras com a dinâmica do processo de reprodução econômica, inclusive exercendo papel de consumidor direto; facilitador da expansão monopolista das empresas dominantes. Essas funções, segundo Mészáros (2002), caracterizaria o Estado como o “[...] fiador geral do modo de reprodução autoritário do capital, reforçando a dualidade entre produção e controle e a divisão hierárquica do trabalho" (MÉSZÁROS, 2002, p. 122).

A (brevíssima) caracterização da reprodução do capital e suas crises inerentes vem a calhar em uma conjuntura que vai passar aos anais como um dos grandes acontecimentos da história brasileira - a deposição da então Presidenta Dilma Rousseff. ${ }^{7}$ Além do pacote de privatizações citado

\footnotetext{
${ }^{6}$ No momento de escrita deste artigo (setembro de 2016), o governo Temer anunciou pacote com 34 projetos de concessões e privatização de empreendimentos na infraestrutura brasileira (aeroportos, portos, rodovias, distribuição de energia, companhias estaduais de água e esgoto) e que teria como propósito a captação de recursos em torno de R 24 bilhões em 2017 e estimular o crescimento econômico e a geração de empregos. No entanto, para viabilizar o projeto de arrecadação de recursos privados, o Governo Federal vai disponibilizar recursos na ordem de R $\$ 30$ bilhões, divididos em R 18 bilhões pelo Banco Nacional de Desenvolvimento Econômico e Social (BNDES) e R \$ 12 bilhões pelo Fundo de Investimento do FGTS (FI-FGTS) (LIS; MARTELLO, 2016). O Estado transfere ativos para a iniciativa privada e ainda oferece empréstimo para que essa reprodução de valor se realize, o que evidencia o papel imiscuído que há entre Estado e capital. No entanto, cabe ressaltar que são medidas que já têm sido executadas em governos anteriores, em especial, de FHC à Dilma.

7 O movimento político que resultou na deposição da então Presidenta Dilma Rousseff foi um exemplo fiel da voracidade com que os setores dominantes agem no intuito de preservar ou recuperar sua margem de ganhos. No primeiro mandato de Dilma (2011-2014), o crescimento econômico ocorreu a uma média de 2,2\%, estagnando, em 2014, em $0,1 \%$, e retraindo, em 2015, para 3,8\%. A crise econômica, que, dentre outras consequências, contribuiu para que, no presente momento, haja em torno de 11,8 milhões de desempregados pelo IBGE, reverberou para uma crise política e culminou na mudança do bloco no poder no âmbito do Governo Federal. Com a presidência da República sob o comando direto do Partido do Movimento Democrático Brasileiro (PMDB) e uma coalizão de partidos que estavam na oposição ou tinham cargos no alto escalão do governo Dilma, Michel Temer tem se proposto a cumprir uma agenda de contrarreformas que as frações dominantes lhe incumbiram.
}

Práxis Educativa, Ponta Grossa, v. 12, n. 3, p. 728-748, set./dez. 2017 Disponível em: <http://www.revistas2.uepg.br/index.php/praxiseducativa> 
em nota, estão na ordem do dia também a limitação dos gastos das esferas de governo com a Proposta de Emenda Constitucional n 241 e a Proposta de Lei Complementar $n^{\circ}$ 257; a contrarreforma da Previdência Social, implicando na instituição da idade mínima para aposentadoria em 65 anos; e a contrarreforma trabalhista, que visa sobrepor as negociações entre sindicatos de trabalhadores e patronais ao que está previsto na legislação trabalhista.

Decerto tais proposições perpassaram e foram implementadas pelos governos petistas mas, por conta de sua base de apoio em setores organizados da classe trabalhadora, nem sempre estes tiveram as condições políticas favoráveis para radicalizá-las, ainda que a privatização direta, por meio de venda de setores produtivos estatais, bem como a indireta, por meio de consórcios e parcerias público-privadas, nunca tenha saído das agendas de política de Estado, independentemente de governo e de crise do capital. ${ }^{8}$ No entanto, sobretudo nesse contexto de ascensão de uma agenda incisiva sobre os direitos sociais, as políticas públicas de educação também se tornam alvo de disputas, provavelmente mais acirradas pelo conteúdo e pela forma das ações sinalizadas a serem empreendidas. ${ }^{9}$

Entre as oscilações que expressam a natureza de crise do sistema capital e as políticas de Estado expressas em políticas de governo, e diante de tantas pautas, nossa opção foi constatar a proposição da instituição da gestão privada-mercantil nas escolas públicas brasileiras por meio de editais de concessão pelo poder estatal, o que, em alguns casos, ganha a denominação de que se trataria de escolas charters como uma das ações determinadas pela natureza político econômica dessa ordem.

\section{Escolas charters estadunidenses}

O modelo da gestão privada em escolas públicas tem se difundido em diversos países, como França, Japão, Inglaterra, Chile, México, Argentina e, sobretudo, consolidado nos Estados Unidos. A ponta de lança dessa nova modalidade de provimento da oferta educativa deu-se a partir da década de 1990, em uma conjuntura de estagnação do crescimento econômico e de instabilidade política frente às demandas da classe trabalhadora diante das mazelas sociais provocadas pelas medidas austeras, neoliberais, implementadas pelos governantes (COUTINHO, 2012; MOTTA, 2012; ALVES, 2013). Nesse contexto, duas questões envolvem a educação escolar pública e o fortalecimento da hegemonia da agenda privada-mercantil nos encaminhamentos de políticas

\footnotetext{
8 Mesmo os ciclos econômicos favoráveis durante o segundo governo de Lula e o primeiro governo de Dilma não estancaram o movimento de privatizações.

9 A agenda privada-mercantil na educação, há muito predominante e com fortes contornos na delimitação e na implementação das políticas públicas, tem conferido muita ênfase na formulação e na instituição da Base Nacional Comum Curricular (BNCC), com vistas a compor um conjunto de conhecimentos "mensuráveis e aferíveis" pelas avaliações padronizadas em larga escala, nacional e internacionalmente, o que também tem implicado em uma devida atenção aos processos formativos dos professores. Outra pauta recorrente é a reforma do Ensino Médio, hoje instituída pela Medida Provisória no 746, de 22 de setembro de 2016; que, entre outras providências, flexibiliza o currículo escolar. Vale também destacar a atuação do movimento Escola sem Partido que, apoiando-se na denúncia de que haveria uma disseminada doutrinação esquerdista nas instituições de ensino, tem se articulado a parlamentares para apresentação de projetos de lei que criminaliza docentes que, no exercício de sua função, problematizem questões que atentem contra os preceitos morais e intelectuais dos pais, inviabilizando a escola como um local da reflexão e circulação de conhecimento. Nesse caso, há uma convergência entre a concepção de educação da agenda privada-mercantil (conservadora) com a agenda ultraconservadora desse grupo social: ambas não veem a escola como espaço de se pensar "[...] os problemas que a humanidade enfrenta no tempo presente" (LEHER, 2016, s/p).
}

Práxis Educativa, Ponta Grossa, v. 12, n. 3, p. 728-748, set./dez. 2017 Disponível em: <http://www.revistas2.uepg.br/index.php/praxiseducativa > 
educacionais: atender as reivindicações da massa de trabalhadores por acesso à escola, restabelecendo a estabilidade política e educando os jovens trabalhadores em ajuste à nova sociabilidade competitiva (MOTTA, 2012; GAWRYSZEWSKI, 2013); e, em tempos de crise econômica, criar possibilidades de ampliar o mercado educacional.

Diante disso, a justificativa pela intervenção na educação pública predominantemente se baseia em argumentos de que se busca maior eficiência e racionalidade na gestão das unidades escolares, pois, diante das recorrentes crises fiscais e legislações que regulam o funcionamento da máquina do Estado, isso criaria uma série de dificuldades para que o serviço fosse prestado a contento. Mencionando o que entenderia como virtudes da gestão privada em escolas públicas, Reynaldo Fernandes, ex-presidente do Instituto Nacional de Estudos e Pesquisas Educacionais Anísio Teixeira (INEP) (2005-2009), menciona que redes de escolas não se submeteriam às regulações previstas pela administração pública, poderiam, por exemplo, ter mais liberdade para gerir o staff, como remunerar os professores de forma diferenciada, de acordo com os índices de aproveitamento nas avaliações externas, o que permitiria elevar a remuneração dos professores "mais eficientes", no sentido de apresentar melhores resultados nessas avaliações, bem como demitir aqueles que não apresentassem resultados a contento (FERNANDES, 2015).

A suposta necessidade de maior agilidade e eficiência para administrar redes de ensino também se ancora no argumento de que a privatização da gestão alavancaria a garantia do "direito à aprendizagem", permitindo que os mais pobres tenham uma educação de mesma qualidade do que a elite e quebrando a segregação de classes e grupos de minorias sociais, bastando escolher as escolas que obtenham melhores resultados nos processos de avaliação (SCHÜLER, 2015). Ou seja, a gestão privada da escola pública faria com que se estimulasse uma competição entre as escolas ${ }^{10}$ e contra as escolas públicas tradicionais ${ }^{11}$, o que, por conta de uma natural ordem espontânea, isso estimularia maior atenção de todo o sistema educacional, gerando, consequentemente, mais qualidade no aprendizado.

Partindo de análise inteiramente oposta sobre o tema, em relação aos autores anteriores, Foster (2013) situa que o movimento em prol da reforma da educação pública nos Estados Unidos expressaria

[...] um produto de contradições impostas externamente que são inerentes à educação na sociedade capitalista, agravadas em nossos tempos pelas condições de estagnação econômica nas economias capitalistas desenvolvidas e pelos efeitos do próprio movimento de reforma conservador. (FOSTER, 2013, p. 86).

De acordo com o que já tratamos na seção anterior, a recessão econômica e o represamento da reprodução de valor leva o capital à busca de encontrar soluções para remediar suas crises. No caso da educação, além de ser um mercado promissor, principalmente nos países de população com baixa escolaridade e com grande demanda de acesso, e que ainda passa por uma crescente exploração do seu "potencial econômico", a escolarização desempenha um papel crucial na (con)formação da força de trabalho. Esta deve desenvolver habilidades específicas requeridas pelo mercado (ainda que

${ }^{10} \mathrm{Em}$ Washington, no período que antecede a matrícula dos alunos, as organizações privadas que atuam junto às escolas charters, as próprias escolas e os grupos de pais organizam um evento no qual fazem um marketing corporativo para atrair as famílias interessadas em matricular novos alunos, e organizações governamentais e não-governamentais promovem um ranqueamento das escolas por meio de seu desempenho como baixa, média e alta performance (ADRIÃO, 2014).

${ }^{11}$ Fazendo referência às escolas regulares do sistema público estadunidense, isto é, não administradas pelo setor privado.

Práxis Educativa, Ponta Grossa, v. 12, n. 3, p. 728-748, set./dez. 2017 Disponível em: <http://www.revistas2.uepg.br/index.php/praxiseducativa > 
mínimas e voltadas ao trabalho simples em boa parcela do contingente) e, sobretudo, moldada por uma moral e por uma ética do trabalho (GRAMSCI, 2001).

$\mathrm{Na}$ crise do capital que atingiu seu apogeu em meados da década de 1970, o ciclo de estagnação econômica dos Estados Unidos foi a brecha para o declínio das despesas com proteção social e Educação Básica, o que acarretou em uma situação em que as escolas públicas tiveram que lidar com um contingente maior de crianças e adolescentes em condição de pobreza. Para lidar com a deterioração das condições das escolas, ocasionadas justamente na aurora do período neoliberal, já com Ronald Reagan na Presidência, foi nomeada, em 1983, uma Comissão Nacional de Educação que emitiu o relatório intitulado $A$ Nation at Risk. No parecer, a Comissão concluiu que o sistema educacional estadunidense estava fracassando devido a fatores endógenos de mau funcionamento do sistema, o que comprometeria a competitividade da nação no cenário internacional. Desse modo, gradativamente os sistemas de ensino estadunidenses foram sendo moldados a funcionar cada vez mais sob princípios corporativos e com ênfase em avaliações padronizadas (FOSTER, 2011). Surgem as escolas charters, isto é, escolas públicas administradas por organizações privadas, de modo a estabelecer metas de desempenho e normas gerais para sua gestão. As chamadas escolas charters seriam, portanto, instituições nominalmente públicas geridas por instituições privadas. ${ }^{12}$ Essas instituições de ensino funcionam segundo normas estabelecidas em contrato de gestão com o poder público sob determinadas condições, dentre as quais, que não haja cobrança de mensalidades ou matrículas ou discriminação no acesso à escola.

No caso das organizações privadas gestoras, estas podem ter ou não fins lucrativos. Mesmo entre as ditas sem fins lucrativos, há uma pluralidade de instituições, desde aquelas que são de base comunitária e independentes até a outras que são geridas por redes em âmbito nacional como a Knowledge is Power Program (KIPP) ${ }^{13}$. O KIPP tem uma rede de 200 escolas em 20 estados, abrangendo em torno de 80.000 estudantes, o que põe o status de empresa sem fins lucrativos questionável. Em 2016, em torno de 60\% das escolas charters nos Estados Unidos seriam de base independente e sem fins lucrativos, enquanto $40 \%$ são administradas por empresas que vêm formando cadeias especializadas para gestão da educação, as chamadas Education Management Organizations (EMOs) (KRAWCZYK, 2016).

A primeira escola charter aberta nos Estados Unidos foi na cidade de Minnesota, em 1992. Atualmente quase $6 \%$ das escolas estadunidenses são administradas por uma organização privada, o que equivale, aproximadamente, a 2,9 milhões de estudantes em 6.723 unidades escolares (MEAD; MITCHEL; ROTHERHAM, 2015). As cidades que, proporcionalmente, concentram mais de $40 \%$

\footnotetext{
12 Adrião (2014) argumenta que, na literatura consultada para realização de sua pesquisa, também pode englobar as escolas privadas subsidiadas por fundos públicos por meio de vouchers ou outras modalidades de financiamento.

13 A rede KIPP é considerada uma Charter Management Organization (CMO) que, declaradamente, teria uma finalidade não lucrativa e que responderia diretamente a um controle de base na própria escola, enquanto as EMOs teriam uma autoridade executiva que responderia diretamente a uma cadeia corporativa e com padrões de desempenho mais rígidos. No entanto, as diferenças apuradas parecem ser deveras sutis, especialmente em se tratando de redes como a KIPP, confirmadas por síntese de Woodworth e Raymond, a serviço da organização Center for Research on Education Outcomes (CREDO): “Thus, one might anticipate greater variance in EMO performance, all else being equal (CREDO, 2013 , p. 5)". Para conhecer mais a rede KIPP, ver em < http://www.kipp.org >.
}

Práxis Educativa, Ponta Grossa, v. 12, n. 3, p. 728-748, set./dez. 2017 Disponível em: <http://www.revistas2.uepg.br/index.php/praxiseducativa> 
dos estudantes da rede pública que estudam em escolas charters são Nova Orleans ${ }^{14}$, Detroit e Washington (ROBERTSON, 2015).

Por suposto, a motivação que move as EMOs é a possibilidade de acumular capital. Desde 1999, a quantidade de EMOs que administra escolas públicas nos Estados Unidos cresceu 328\%, subindo de 360 para 1.541 unidades em 2009 (ROBERTSON, 2015). Com o fortalecimento das EMOs, constituiu-se uma cadeia corporativa que opera em solo estadunidense. Segundo o Center for Research on Education Outcomes (CREDO), instituto de pesquisa vinculado à Universidade de Stanford, existiriam atualmente 38 EMOs no país que controlam pelo menos 3 unidades escolares cada (WOODWORTH; RAYMOND, 2013).

O crescimento das escolas charters, sobretudo na forma de cadeias de gestão na educação (CMO e EMOs) está atrelado à fortíssima influência de fundações privadas de grandes corporações, como a Bill \& Melinda Gates Foundation (Microsoft, empresa de TI), a Walton Family Foundation (rede de supermercado varejista Walmart), a Eli \& Edythe Broad Foundation (ramo imobiliário) e a Michael \& Susan Dell Foundation (Dell, empresa de TI), além de think tanks apoiadores, bilionários como o Chief Executive Officer (CEO) da empresa Netflix, Reed Hastings, e as próprias frações políticas que estão no comando das esferas de governo nos Estados Unidos.

Essas fundações praticam o que Foster (2013) denominou "filantropia de risco" ou "filantrocapitalismo", pois suas doações estão destinadas a investimentos rigorosamente escolhidos e que dê retorno nos fins propostos. Os exemplos são inúmeros e tomariam um espaço enorme do artigo, mas, recentemente, foram noticiados planos de investimento por parte de Eli Broad no montante de US $\$ 490$ milhões para construção de 260 novas escolas charters em Los Angeles; a família Walton anunciou investimentos na ordem de 200 milhões de dólares nos próximos anos; e o CEO da Netflix, Reed Hastings, anunciou que criaria uma fundação filantrópica com seu nome investindo US\$100 milhões no Vale do Silício ${ }^{15}$. Diante de tanto investimento por parte de grandes corporações, esperava-se que fosse potencializar os níveis de desempenho definidos nas avaliações em larga escala instituídas pela lei No Child Left Bebind (NCLB), em $2001^{16}$.

14 O caso de Nova Orleans é emblemático, pois sua rede atualmente foi quase inteiramente "charterizada" (91\%) após a devastação em 2005 provocada pelo furacão Katrina. Na ocasião, o índice de desempenho nas avaliações de larga escala dos estudantes caiu significativamente e as escolas charters foram alçadas a condição de alavancar as notas. A expectativa de ressurreição após uma destruição como ocorrera se assemelha a analogia que Naomi Klein (2008) denominou como "doutrina de choque" do capitalismo contemporâneo, em que se utiliza uma profunda crise para entregar esferas do Estado a investidores privados multiplicarem seus lucros e instituir reformas permanentes.

15 As notícias podem ser consultadas em: <https://dianeravitch.net/2015/09/22/los-angeles-times-reveals-eli-broads490-million-plan-to-expand-privatization-in-l-a/> (no caso de Eli Broad); <http://www.waltonfamily foundation.org/grants/public-charter-startup-grants $>$ (no caso da família Walton); <http://www.salon.com /2016/01/17/netflix_founder_drops_100_milli_on_the_silicon_valley_led_crusade_to_destroy_our_public_schools_pa rtner/ > (no caso de Reed Hastings).

${ }^{16}$ Em síntese, a legislação NCLB consistia em que todos os estados deveriam desenvolver suas próprias avaliações com três níveis de desempenho (básico, proficiente e avançado), condicionadas à liberação de recursos federais para educação. Os estados eram obrigados a aplicar testes para avaliar os estudantes de terceira à oitava séries, anualmente, para mensurar a proficiência em leitura e em matemática. Essa mensuração deveria ser capaz de desagregar as pontuações em termos de condição de baixa renda, raça, etnia, nível de dificuldade de aprendizagem e proficiência limitada em língua inglesa. Cada estado deveria elaborar um cronograma projetando a meta para 100\% de seus alunos atingirem a proficiência até 2014, e as escolas que não atingissem o Adequate Yearly Progress (AYP) estariam sujeitas a "ações corretivas", como mudanças curriculares, demissão no quadro de funcionários ou reestruturação da própria escola, incluindo a alternativa coercitiva de ter de se transformar em escola charter. Como conclusão do processo, todos os

Práxis Educativa, Ponta Grossa, v. 12, n. 3, p. 728-748, set./dez. 2017 Disponível em: <http://www.revistas2.uepg.br/index.php/praxiseducativa> 
Gestão privada de escolas públicas da Educação Básica: um novo mercado sob a tutela do Estado

Em aspecto comparativo sobre o desempenho na National Assessment of Educational Progress (NAEP), entre as escolas públicas tradicionais e as escolas charters, as opiniões são controversas. Entre os apoiadores das escolas charters, Mead, Mitchel e Rotherham (2015) expõem que essas instituições têm um melhor aprendizado em matemática e leitura, sobretudo conseguindo melhores resultados com os grupos de minorias sociais, como os negros, os hispânicos e as pessoas com deficiência (segundo os autores, os índices de desempenho nas avaliações cresceram entre 6 e 36\%, a depender da disciplina e da zona geográfica). A explicação dos autores consiste em que as escolas são constantemente supervisionadas em termos de "controle de qualidade", chegando ao ponto de serem fechadas, caso não atendam às expectativas indicadas pelo NAEP, forçando para cima os níveis de desempenho.

Já os críticos das escolas charters não associam uma relação de causalidade ao melhor desempenho no NAEP e a gestão privada nas escolas públicas estadunidenses. Ravitch (2013) infere que, apesar do investimento do bilionário ex-Prefeito de Nova Iorque Michael Bloomberg na expansão das escolas charters e nos preceitos da NCLB para aumentar os níveis de desempenho, a suposta tendência de elevar os níveis de desempenho escolar foi insignificante, e a cidade permanece abaixo da média nacional, tanto em matemática quanto em leitura.

O estudo de Mungal (2016) atesta que, durante os onze anos de governo de Bloomberg (2002-2013), foram fechadas 162 escolas públicas com baixo índice de desempenho, ao passo que expandiu para 183 escolas charters na cidade, especialmente com a cadeia Success Academy ${ }^{17}$. O mesmo estudo dá conta de que o orçamento da educação por estudante nas escolas públicas seria de US $\$ 19,076$, enquanto nas escolas charters era reduzido para US $\$ 13,527$.

O aspecto que tange aos professores é deveras importante, pois existe em Nova Iorque uma estrutura paralela de educação com a existência de programas alternativos de certificação de docentes, iniciada no final dos anos 1970, mas que tomou corpo a partir dos anos 1990, com a emergência das escolas charters. Essa estrutura paralela foi desenvolvida devido aos laços estabelecidos entre as organizações não-governamentais Teach for America (TFA) ${ }^{18}$ e Relay Graduate School of Education ${ }^{19}$, e o Departamento Municipal de Educação de Nova Iorque. Os candidatos a esse tipo de certificação, não necessariamente formados ou em formação como professores, mas em nível

estados foram obrigados a participar da avaliação federal, o National Assessment of Educational Progress (NAEP) (FOSTER, 2011).

17 Até o momento, a rede Success Academy tem atuação concentrada em Nova Iorque arrebatando cerca de um terço das escolas charters na cidade, possuindo 34 escolas e 22.000 estudantes sob sua gestão. A rede tem chamado muito a atenção dos "filantrocapitalistas", pois seu índice de desempenho nos testes de larga escala tem sido altíssimo, sendo considerado um "investimento seguro" e tem em seu conselho executivo diversos operadores de fundos hedge. Ver mais detalhes em: <http://www.nytimes.com/2015/07/31/nyregion/success-academy-receives-gift-for-new-schools.html>. Acesso em: 2 nov. 2016.

18 A Teach for America é uma organização majoritariamente sustentada com financiamento privado de fundações semelhantes às já citadas anteriormente e tem se destinado a recrutar e formar pessoas para trabalharem na educação em processos de capacitação que duram em média 6 semanas.

19 A Relay Graduate School of Education é uma organização que tem origem em outro programa de certificação de professores, o Teacher $U$ da Hunter College, e que se destina especificamente a capacitar pessoas para trabalharem como professores de escolas charters, especialmente nas cadeias da rede KIPP, Achievement First e Uncommon Schools. Quando David Steiner, ligado à Hunter College, foi promovido para o Conselho de Comissários Regentes de Educação de Nova Iorque, em 2009, ele pôs em prática novas iniciativas para certificar pessoas para o magistério e foi viabilizada a criação da Relay (MUNGAL, 2016).

Práxis Educativa, Ponta Grossa, v. 12, n. 3, p. 728-748, set./dez. 2017 Disponível em: <http://www.revistas2.uepg.br/index.php/praxiseducativa> 
superior, são recrutados pela TFA e treinados pela Relay. Logo que terminam sua capacitação, são inseridos para atuar nas escolas charters e passam a receber uma remuneração (MUNGAL, 2016), porém menor do que a dos professores das escolas tradicionais (KRAWCZYK, 2016; CANNATA; PEÑALOZA, 2012).

O pressuposto discursivo que move a ênfase em recrutar e treinar essas pessoas é o de atender à alta demanda por professores nas escolas, que precisaria ser suprida rapidamente e não pode se tornar refém da "burocracia, ineficiência e regulação" das instituições de ensino universitárias na formação docente; e atingir os níveis de desempenho esperados pelas avaliações de larga escala. A agenda desregulacionista entende que é necessário estabelecer uma concorrência entre as escolas para pressionar as instituições a serem mais inovadoras e exitosas nos resultados, porque estariam sob o risco de perderem seus "consumidores". Assim, segundo Mungal (2016, p. 8, tradução nossa): "A agenda desregulacionista acredita que o treinamento acadêmico intensivo não é essencial, mas em vez disso coloca maior ênfase no tempo dentro da sala de aula". Logo, trata-se de cursos que enfatizam a prática como um treinamento em serviço, desvinculado de uma sólida formação teórica e articulada ao trabalho pedagógico docente.

Esse tipo de agenda para a formação e a "qualificação" de professores tem reverberado em severas críticas às escolas charters, especialmente aquelas administradas como CMOs e EMOs, que se utilizam de uma série de estratégias para aumentar seu faturamento, entre elas a redução dos custos, provocando um confronto direto com os sindicatos. Em relação ao rebaixamento dos custos para ampliar a margem de lucro, Foster (2013) critica que, nas escolas charters, o tamanho das turmas é frequentemente maior do que nas escolas públicas, de que há uma redução dos serviços extras oferecidos às famílias como alimentação escolar, transporte e reforço nas disciplinas, e o currículo é apoiado em apostilas voltadas ao "sucesso" na testagem de habilidades cognitivas pré-determinadas nas avaliações de larga escala, o que, supostamente, evitaria gastos com a repetência de alunos.

Em relação aos sindicatos, Dwight Holmes, pesquisador da Associação Nacional de Educação, em entrevista a Nora Krawczyk (2016), expõe que as organizações que atuam em prol das escolas charters têm dificultado ao máximo o livre exercício sindical, inclusive coagindo e constrangendo a participação dos professores nos sindicatos. $O$ mesmo autor sintetiza que os professores das escolas charter tendem a ser mais jovens, menos qualificados, com menos experiência, recebem menor remuneração e benefícios e volume de trabalho superior. Holmes dá o exemplo de que, na Flórida, o salário médio anual dos professores nas escolas charters em 2011-2012 era de US\$ 38.459 , enquanto nas escolas públicas tradicionais é de $\$ 46.273$.

Constatação semelhante encontra-se no estudo de Cannata e Peñaloza (2012). Os autores fizeram levantamento do estado da arte em outras pesquisas e realizaram a sua própria pesquisa survey online com mais de 2.000 professores de escolas públicas e charters. Em síntese, os resultados do survey atestaram que os professores das escolas charters têm, em média, sete anos de experiência no magistério contra 13 das escolas públicas tradicionais (EPT); que os professores das EPTs têm maior certificação docente, principalmente em nível de Mestrado (53\% EPT x 36\% charters); e que a maior parte dos professores que trabalhava nas escolas charters lá estava porque não conseguia encontrar empregos em escolas públicas tradicionais.

Ainda identificamos uma série de denúncias de que as organizações que dirigem as escolas charters estadunidenses sequer têm respeitado as legislações vigentes no país, de modo a maximizar seus ganhos por meio de violações de toda ordem. Ao passo que se queixam das regras onerosas que

Práxis Educativa, Ponta Grossa, v. 12, n. 3, p. 728-748, set./dez. 2017 Disponível em: <http://www.revistas2.uepg.br/index.php/praxiseducativa $>$ 
precisariam cumprir para gerir a escola pública, o que dificultaria a liberdade para inovar, pululam acusações de que tais corporações realizam práticas ilícitas a fim de romper tais barreiras, como: criação de organizações sem fins lucrativos de fachada para administrar o capital obtido com a gestão escolar, aluguel de imóveis que seriam destinados para criar escolas, fraude nos exames de desempenho, desvio de recursos e intimidação contra professores que sinalizam se sindicalizar, dentre outros ${ }^{20}$.

Tendo em vista a exposição e a controvérsia sobre a origem e o funcionamento das escolas charters estadunidenses e que se trata de um modelo que vem sendo defendido para resolução dos problemas educacionais brasileiros, seguiremos analisando-o na realidade brasileira.

\section{Escolas brasileiras de gestão privada}

Nesta seção do artigo, pretendemos discutir a respeito de como a pauta da gestão privada em escolas públicas brasileiras se encontra no tempo presente. Nosso foco de estudo concentra-se, sobretudo, nos processos recentes engendrados pelos governos estaduais de Goiás (GO) e Mato Grosso (MT). Apesar disso, não ignoramos e desconhecemos outros processos já em curso que procuram promover as parcerias público-privadas como uma convergência "natural" de interesses em torno da educação ${ }^{21}$.

Considerando que estamos trabalhando no pressuposto de que há uma série de propostas de mudanças, reformas, ajustes, e os diversos sinônimos que poderiam caber, em curso; que, em última instância, expressam a finalidade de derrubar limites para ampliação da esfera do capital em sua produção e reprodução social, é importante destacar que a promoção da Reforma do Estado (Emenda Constitucional 19/1998), sua consequente lei das Organizações Sociais (9.637/98) e a lei das Parcerias Público-Privadas (11.079/2004) fornecem os instrumentos jurídicos para que essa modalidade de gestão privada encontre amparo legal e tente se afirmar como legítima.

As formulações em torno dessas legislações preconizam que o aparelho de Estado deveria ser mais permeável à contribuição que o setor privado teria a oferecer, pois seria uma forma de "publicizá-lo", por meio da descentralização de atribuições às unidades subnacionais e permitindo uma cidadania participativa da sociedade civil. Desse modo, os ideólogos da Reforma do Estado entendem que se romperia com a visão dicotômica entre o público e o privado, abrindo espaços para que instituições da sociedade civil (concebida como "terceiro setor" 22 ) pudessem prestar os serviços públicos que eram realizados de forma ineficaz pelo Estado (BRESSER PEREIRA; GRAU, 1999).

${ }^{20}$ Essas denúncias estão compiladas na reportagem How charter schools break the rules - and don't seem to care, disponíveis em <http://www.alternet.org/education/charter-schools-break-rules>. Acesso em: 3 nov. 2016.

21 A exemplo de Pernambuco, a incorporação do modelo charter deu-se como experiência piloto por meio do projeto Procentro, entre 2005 e 2007, com parceria público-privada entre a Secretaria de Educação do Estado e o Instituto de Corresponsabilidade pela Educação (ICE). O ICE, uma organização privada que na sua fundação teve apoio da empresa multinacional Philips, da Tintas Coral, do Eurobank e da empresa de capital misto do setor elétrico Chesf, tem como instituições executores de projetos o Instituto Qualidade no Ensino (IQE), liderado por Marcos Magalhães Presidente da Philips para a América Latina, à época de implementação do projeto; e o Instituto Alfa e Beto (IAB), dirigido por João Batista Oliveira, ex-secretário executivo do MEC, no governo de Fernando Henrique Cardoso). (Ver SARDINHA, 2013).

22 Típica concepção liberal que separa as esferas do Mercado, do Estado e da Sociedade Civil qualificando funções colaborativas e harmoniosas entre elas, porém de caráter distintos.

Práxis Educativa, Ponta Grossa, v. 12, n. 3, p. 728-748, set./dez. 2017 Disponível em: <http://www.revistas2.uepg.br/index.php/praxiseducativa > 
Corroborando com essa maior permeabilidade entre a esfera pública e privada ou, em outros termos, a disputa pela apropriação do fundo público pelo setor privado, tramita no Senado o Projeto de Lei 739/2015, de autoria do Senador Cristovam Buarque (PPS), que institui a permissão para que as organizações sociais que possuam contratos de gestão com o poder público recebam recursos do Fundo de Manutenção e Desenvolvimento da Educação Básica e de Valorização dos Profissionais de Educação (Fundeb). Na justificativa, evoca-se que tal medida atenderá a introdução de "práticas modernas de gestão na educação", incluindo as escolas charters (BRASIL, 2015). Destacamos, também, o Plano Nacional de Educação (PNE) 2014-2024 (Lei 13.005/2014) - que delibera que os recursos públicos destinados à manutenção e ao investimento na educação não serão exclusivos para o ensino público (COLEMARX; ADUFRJ, 2014).

Diversas iniciativas têm sido aventadas por governadores no sentido de transferir a gestão escolar para a iniciativa privada. Duas iniciativas que tiveram grande repercussão em 2015/2016 foram as dos governos estaduais de Goiás e Mato Grosso, por isso nos concentraremos nelas.

\section{Goiás}

Em janeiro de 2015, a Secretaria de Educação, Cultura e Esporte de Goiás (SEDUCE), por meio da Secretária Raquel Teixeira, visitou os Estados Unidos e tomou contato direto com as experiências de gestão privada de escolas públicas estadunidenses. O argumento do governador Marconi Perillo para realizar tal iniciativa ampara-se no desejo de que "[...] o filho do pobre estude em escolas com padrão de escola de rico" (VITOR, 2015) e de que os funcionários contratados pelo regime celetista são mais produtivos porque temem ser substituídos, caso não atendam às expectativas sobre seu trabalho (VITOR, 2015).

Em 14 de outubro de 2015, Perillo assinou o Decreto $N^{\circ} 8.469$, que determinava que a SEDUCE realizasse uma seleção até dia 31 de dezembro de 2015 das organizações sociais interessadas em celebrar contratos de gestão de até 30\% das unidades escolares que integram as subsecretarias de Educação de Goiânia, Aparecida de Goiânia, Anápolis, Trindade e do entorno do Distrito Federal (GOIÁS, 2015).

Em 8 de dezembro de 2015, foi publicado no Diário Oficial de Goiás o processo de transferência da gestão de unidade escolares da rede pública estadual a Organizações Sociais. A intenção era que as entidades começassem a atuar no primeiro semestre de 2016. No mesmo dia, os profissionais de educação da rede estadual reuniram-se para uma audiência pública convocada pelo Fórum Nacional de Educação (FNE) ${ }^{23}$ a fim de debater com a Secretaria de Educação a proposta de privatização das escolas públicas. Com a ausência da Secretária Raquel Teixeira e a publicação do processo de transferência no Diário Oficial, no dia seguinte, o movimento secundarista deflagrou a primeira ocupação de escola no estado e que se estendeu em um total de 28 escolas ocupadas em um processo de luta intensa até o final de fevereiro de 2016. Durante o processo de ocupação, o Governo Estadual fez várias tentativas para acabar com o movimento, solicitando o cancelamento do fornecimento de água e luz para a escola, além de pedido de reintegração de posse, seguidas de

${ }^{23}$ O FNE é um órgão de Estado, definido como "espaço inédito de interlocução entre a sociedade civil e governo", instituído pela Portaria no. 1407/2010.

Práxis Educativa, Ponta Grossa, v. 12, n. 3, p. 728-748, set./dez. 2017 Disponível em: <http://www.revistas2.uepg.br/index.php/praxiseducativa > 
desocupações violentas realizadas pela polícia ${ }^{24}$.

No dia 4 de janeiro de 2016, a SEDUCE publicou o edital de chamada das entidades no site da Secretaria, abrangendo 23 unidades escolares de cinco cidades da macrorregião de Anápolis. No dia 15 de fevereiro de 2016, foi realizada a abertura dos envelopes das dez Organizações Sociais (OS) interessadas em gerir as escolas do estado; entretanto, todas tiveram pendência em documentação. Registra-se que a abertura dos envelopes com as candidaturas foi realizada sob fortíssimo aparato policial para impedir qualquer manifestação que pudesse atrapalhar o andamento dos trabalhos. Tendo em vista a pressão do movimento estudantil e de profissionais da educação, o Ministério Público de Goiás, o Ministério Público Federal e o Ministério Público de Contas do Estado entraram com ação civil recomendando a suspensão do edital até que fossem modificados itens considerados inconstitucionais. Assim, a Secretaria informou que as organizações concorrentes foram desclassificadas por não terem cumprido todos os requisitos exigidos pelo edital e o processo foi adiado para o segundo semestre de 2016.

Em junho de 2016, a SEDUCE Goiás promoveu um workshop que reuniu representantes de Organizações Sociais, gestores escolares e técnicos do Banco Mundial a fim de debater, compartilhar experiências de "sucesso" e qualificar o processo de transferência da rede pública para Organizações Sociais. Na ocasião, a Secretária Raquel Teixeira explicou as mudanças no edital, tais como limite de teto para salário dos diretores, regras contra nepotismo, apresentação de um projeto de gestão e a criação de um núcleo no governo para acompanhar a implantação da gestão privada na Educação (SEDUCE, 2016).

No dia 19 de setembro, a SEDUCE Goiás realizou novo processo de qualificação de Organizações Sociais e quatro foram qualificadas para prosseguir na concorrência: Instituto Brasileiro de Cultura, Educação, Desporto e Saúde (Ibraceds), Associação Grupo Tático de Resgate (GTR), Instituto de Educação, Cultura e Meio Ambiente (ECMA) e Instituto de Educação e Cidadania (IEC). Três destas (Ibraceds, GTR e ECMA) possuem algum vínculo com o governador Perillo e seus sócios ou ex-sócios envolvidos em denúncias de corrupção, e a IEC tem seu presidente como dono de escola particular. Tal constatação sobre as OSs qualificadas para atuar no processo licitatório permite afirmar que nenhuma dessas tem perfil filantrópico sem fins lucrativos, conforme tem sido reiterado pela Secretária Raquel Teixeira (SAADI, 2016).

A educação do estado de Goiás, apesar de contar com 6.470 professores temporários (35,5\% dos docentes) na rede estadual (INEP, 2016), possui o melhor índice entre todos os estados brasileiros no IDEB, porém a Secretária de Educação justifica, para a adoção do modelo de OSs na gestão escolar, a baixa qualidade no ensino argumentando que apenas $9 \%$ dos alunos têm conhecimento adequado em matemática. Desse modo, podemos inferir que a ação do Governo Estadual se norteia pela abertura de um novo espaço de exploração econômica para a iniciativa privada.

24 Foi publicado pela agência midiativista Ponte que existe um grupo no aplicativo WhatsApp formado por representantes da SEDUCE, incluindo a própria Secretária Raquel Teixeira, a Polícia Militar, Civil e a Secretaria de Segurança Pública, que tem monitorado o movimento de estudantes e professores, a fim de realizarem ações de cooptação, intimidação e repressão, utilizando de estratégias de espionagem nas reuniões, detecção de estudantes e professores que exercem posição de liderança e planejamento de ações que envolvam agentes químicos. Conferir reportagem em: <http://ponte.org/grande-irmao-goias/>. Acesso em: 2 nov. 2016.

Práxis Educativa, Ponta Grossa, v. 12, n. 3, p. 728-748, set./dez. 2017 Disponível em: <http://www.revistas2.uepg.br/index.php/praxiseducativa $>$ 


\section{Mato Grosso}

Pouco tempo depois do início do ano letivo de 2016, foi publicado, no mês de abril, o edital de "Procedimento de Manifestação de Interesse" com a intenção de atrair empresas interessadas em elaborar um projeto de parceria público-privada para transferir a gestão de 76 unidades escolares e 15 Centros de Formação e Aperfeiçoamento Profissional (Cefapros) para uma organização privada cuidar de serviços de construção, reforma, ampliação, gestão, manutenção e operacionalização de serviços não pedagógicos dessas escolas. A justificativa apresentada no edital para a terceirização do serviço é melhorar a estrutura das unidades. "O estado de Mato Grosso, assim como muitos entes da nossa federação, padece de condições mínimas de estrutura física para a maioria das escolas, tendo como consequência imediata o significativo agravamento do ambiente escolar" (SEDUC-MT, 2016).

O processo de transferência da gestão de escolas públicas tem sido operacionalizado pela MT Participações e Projetos (MT-PAR ${ }^{25}$, uma empresa de economia mista criada pelo Governo Estadual de Mato Grosso em 2013, que tem uma de suas premissas viabilizar as parcerias público-privadas.

Diante da situação colocada de iminente privatização de parte da rede estadual, os profissionais de educação decretaram greve a partir de 31 de maio de 2016, com a reivindicação de reposição salarial e aumento real perante a inflação, abertura de concurso público ${ }^{26}$ e suspensão imediata da implantação da Parceria Público-Privada (PPP) na educação (SINTEP-MT, 2016) e aproximadamente 25 escolas foram ocupadas por estudantes secundaristas.

Em 5 de agosto, os docentes, em assembleia, aceitaram a proposta do Governo de recomposição salarial e resolveram por interromper a greve. Também foi definida a elaboração de um calendário de concurso público, a suspensão integral do edital das Parcerias Público-Privadas (PPPs) e a convocação das conferências participativas para debater o assunto. O acordo foi firmado entre Sindicatos dos Trabalhadores do Ensino Público (Sintep-MT), Secretaria de Estado de Educação (Seduc-MT), com intermediação do Ministério Público Estadual (MPE) e Tribunal de Justiça ${ }^{27}$ (TJMT).

Sob a acusação de querer privatizar a rede de ensino, o governador de Mato Grosso, Pedro Taques, entrou em embate direto contra o Sindicato dos Trabalhadores no Ensino Público de Mato Grosso (Sintep-MT), argumentando que: "Nós não vamos privatizar as escolas. Isso é uma mentira, eu vou repetir, uma mentira do Sindicato dos Profissionais da Educação [Sintep]. Estão mentindo aos pais e aos alunos. [...]. O sindicato está mentindo que nós cobraremos mensalidade. Eu sou contra a privatização do ensino público" (HOLLAND, 2016) ${ }^{28}$.

\footnotetext{
25 A MT-PAR foi instituída por meio da Lei 9.854/2012 e tem propósito semelhante a BNDESPar, podendo emitir títulos públicos (debêntures) para captar recursos da iniciativa privada, além de poder constituir participação acionária em empresas de capital aberto.

26 No Mato Grosso, a questão da abertura do concurso público para o magistério é pertinente, pois a maioria dos professores que atuam na rede estadual não entraram via concurso público, mas sim por meio de processos seletivos temporários que apresentam condições mais precárias de vínculo trabalhista do que os professores efetivos, o que culminou, em 2015, na composição: 9.087 professores efetivos e 12.721 professores temporários, representando 58,33\% do total (INEP, 2016).

27 Mais informações detalhadas disponíveis em: <http://www.atribunamt.com.br/2016/08/professores-suspendem-agreve-aulas-na-cidade-nao-serao-reiniciadas-na-2a/>. Acesso em: 2 nov. 2016.

${ }^{28} \mathrm{Em}$ resposta, o sindicato publicou em sua página: “[...] o Sintep-MT considera a atitude do Governo, em dizer que 'mente' sobre o processo de terceirização/privatização, como leviana. 'Qualquer pessoa que entenda a língua portuguesa
}

Práxis Educativa, Ponta Grossa, v. 12, n. 3, p. 728-748, set./dez. 2017 Disponível em: <http://www.revistas2.uepg.br/index.php/praxiseducativa > 
O Governo Estadual tem argumentado que terceirizar a gestão escolar não é privatizar, pois privatização seria a venda das escolas, e que a intenção seria apenas separar a gestão educacional e a gestão dos processos administrativos. No entanto, questionamos tal afirmação, pois entendemos que essa separação vai promover uma subordinação da gestão educacional a interesses externos e alheios à rotina da vida escolar. O que ocorre é que os estados estão iniciando um processo de privatização educacional, cada um ao seu modo, mas que culminam na transferência de ativos ao empresariado.

\section{Considerações finais}

Visando problematizar a agenda privada-mercantil que se apresenta em meio à nova mediação no âmbito das últimas formulações de políticas públicas da Educação Básica brasileira - as organizações sociais de interesse público e de direito privado -, destacamos um vértice que consideramos o mais promissor no processo de consolidação de sua hegemonia: a gestão privada de escolas públicas nos moldes das escolas charters estadunidenses.

Vimos que essa nova mediação histórica que desponta é regulamentada e se torna protagonista no setor educacional público em meio à intensificação da crise do capital e sob a tutoria do Estado. A "reforma" do Estado operada nos anos 1990 e as subsequentes regulamentações das organizações sociais e das parcerias público-privadas criaram as condições favoráveis para fortalecer a agenda privada-mercantil. As contradições que o próprio sistema capital determina incidem em medidas de maior ou menor controle conforme conjuntura política. Isto é, operam-se ações voltadas a gerenciar as crises do capital, por meio do rebaixamento dos custos da produção e da criação de novos mercados, e introduzem mecanismos que amenizem as tensões advindas dos movimentos de resistência organizados pelos trabalhadores no enfrentamento das medidas austeras voltadas a dinamizar ou a potencializar a acumulação do capital.

No sistema público de ensino, as escolas charters estadunidenses expressam claramente esses dois momentos de intervenção, econômica e político-ideológica. Por um lado, abre possibilidades de ampliar a acumulação do capital criando novos nichos de mercado no âmbito da educação escolar e ainda subsidiados, legalmente, por recursos públicos; o que atrai ainda mais investidores de educação, pois garante a parcela de lucro. Por outro, legitima a atuação privada-mercantil, difundindo a crença de que a gestão privada, evidente e naturalmente, possui maior eficiência e "qualidade"; nesse sentido, os empresários podem "doar" seu tino para negócios e criar as condições para estabelecer a "igualdade de oportunidades para todos" em um sistema marcadamente desigual - o "filantrocapitalismo". Quem iria se contrapor ao discurso de melhoria da qualidade do ensino público e de equalização das oportunidades educacionais?

A penetração da lógica mercantil nos espaços de formação humana traz inúmeras implicações no tocante à função social da escola, à concepção de educação restrita à lógica do capital (capital humano e capital social) e ao esvaziamento do caráter público da educação como direito social, entre outras que não pudemos tratar no âmbito deste artigo. Apresentamos algumas decorrências dessa

vai ler o documento e entender que o Governo está repassando para a iniciativa privada os serviços de construção, reforma, manutenção, infraestrutura, gestão, e os servidores “não” pedagógicos. [...]'. O Sintep-MT é totalmente contrário as discussões paralelas que o governo faz na tentativa de dissuadir a categoria de que não há processo privatista no Edital 001/2016. Defende a garantia das discussões democráticas, em que existam espaços para se expor o contraditório, como são as Conferências [...]”. Disponível em: <http://sintep2.org.br/sintep/exibir.php?exibir=1\&id_l=429>. Acesso em: 2 nov. 2016.

Práxis Educativa, Ponta Grossa, v. 12, n. 3, p. 728-748, set./dez. 2017 Disponível em: <http://www.revistas2.uepg.br/index.php/praxiseducativa > 
lógica orientada “[...] para a expansão e movido pela acumulação" (MÉSZÁROS, 2002, p. 100) no sistema público de ensino, destacadamente, no tocante à gestão privada de escolas públicas da Educação Básica, trazendo o exemplar modelo das escolas charters estadunidenses. Além disso, considerando a crescente tendência de implementação desse modelo nas redes públicas brasileiras, abordamos as redes estaduais de ensino de Goiás e de Mato Grosso, enfatizando as tensões políticas que as engendram.

Tais tensões, consideramos, não se restringem a questões econômico-corporativas, mas éticopolíticas. Ao analisar essa tendência na perspectiva da totalidade, ela elucida que a racionalidade da agenda privada-mercantil na educação implicará em sequelas profundas no âmbito da formação humana. Por em tela a pauta privada-mercantil para a educação brasileira passa pela necessidade de conferir as condições objetivas e estruturais de nosso sistema de ensino público. Que implicações teria a educação pública como mercadoria, isto é, extrair mais valor por meio da redução do custo na contratação de professores, do enxugamento do currículo escolar, do elevado quantitativo da relação professor-aluno por turma.... - em um país em que o sistema público de ensino além de atender a grande parte da população estudantil na Educação Básica já o faz, historicamente, de forma precária e desigual? O que significará a "livre escolha" da escola dirigida pelos resultados determinados por organizações econômicas, como a OCDE e a OMC, que operam em favor da mais acumulação do capital e do mercado como regulador da vida? Essas, entre outras, são questões centrais.

A agenda privada-mercantil para a educação pública confere que estamos diante de uma acirrada luta de classes. Precisamos, assim, armar-nos para desvelar seu caráter de classe.

\section{Referências}

ADRIÃO, T. Escolas charters nos EUA: contradições de uma tendência proposta para o Brasil e suas implicações para a oferta da educação pública. Educação e Filosofia, Uberlândia, v. 28, n. especial, p. 263-282, 2014.

ADRIÃO, T.; BEZERRA, E. P. O setor não lucrativo na gestão da educação pública: corresponsabilidade ou debilidade. Currículo sem Fronteiras [online], v. 13, n. 2, p. 256-268, maio/ago. 2013.

ALVES, G. Crise de valorização e precarização estrutural do trabalho. In: ALVES, G. Dimensões da precarização do trabalho: ensaios de Sociologia do Trabalho. Bauru: Canal 6, 2013.

BRASIL. Plano diretor da reforma de Estado. Brasília, 1995. Disponível em: <http://www.bresserpereira.org.br/Documents/Mare/Planodiretor/Planodiretor.Pdf > . Acesso em: 2 nov. 2016.

BRASIL. Projeto de Lei do Senado no 739/2015. Altera a Lei no 11.494, de 20 de junho de 2007, que regulamenta o Fundo de Manutenção e Desenvolvimento da Educação Básica e de Valorização dos Profissionais da Educação - FUNDEB, para possibilitar a distribuição de recursos a organizações sociais e a instituições comunitárias, confessionais ou filantrópicas que atuem em qualquer das etapas e modalidades da educação básica. Senado Federal. Disponível em:

Práxis Educativa, Ponta Grossa, v. 12, n. 3, p. 728-748, set./dez. 2017 Disponível em: <http://www.revistas2.uepg.br/index.php/praxiseducativa $>$ 
<https://www25.senado.leg.br/web/atividade/materias/-/materia/124052>. Acesso em: 29 set. 2016.

BRESSER PEREIRA, L. C.; GRAU, N. C. Entre o Estado e o mercado: o público não-estatal. In: BRESSER PEREIRA, L. C.; GRAU, N. C. (Orgs.). O público não-estatal na reforma do Estado. Rio de Janeiro: Clad, FGV, 1999.

CANNATA, M.; PEÑALOZA, R. Who are charter school teachers? Comparing teacher characteristics, job choices, and job preferences. Education Policy Analysis Archive, Arizona, v. 20, n. 29, p. 1-25, set. 2012.

CIAVATTA, M. O conhecimento histórico e o problema teórico-metodológico das mediações. In: FRIGOTTO, G.; CIAVATTA, M. (Orgs.). Teoria e educação no labirinto do capital. 2. ed. Petrópolis: Vozes, 2001. p.130-155.

COLEMARX; ADUFRJ. Coletivo de Estudos em Marxismo e Educação. Seção Sindical dos docentes da Universidade Federal do Rio de Janeiro. Plano Nacional de Educação 2011-2020: notas críticas. Rio de Janeiro: ADUFRJ, 2014. Disponível em: <http://www.colemarx.com.br/pne2011-2020/>. Acesso em: 2 nov. 2016.

COUTINHO, C. N. A época neoliberal: revolução passiva ou contra-reforma? Revista Rumos, Marília, v. 49, n. 1, p. 117-126, jan./jun. 2012.

FERNANDES, R. Desafios da Educação. Escolas Charter. Univesp TV, 22 abr. 2015. Disponível em: <https://www.youtube.com/watch?v=ReNuR6E0yyU>. Acesso em: 29 set. 2016.

FOSTER, J. B. Educação e a crise estrutural do capital: o caso dos Estados Unidos. Perspectiva, Florianópolis, v. 31, n. 1, p. 85-136, jan./abr. 2013.

GAWRYSZEWSKI, B. Políticas de educação, hegemonia e territórios pacificados: estratégias contemporâneas para a gestão da governabilidade. 2013. 282 f. Tese (Doutorado em Educação) Universidade Federal do Rio de Janeiro, Rio de Janeiro, 2013.

GOIÁS (Estado). Decreto no 8.469, de 14 de outubro de 2015. Secretaria de Estado da Casa Civil. Goiânia, GO. 2015.2 Disponível em: <http://www.gabinetecivil.goias.gov.br/decretos/numerados/2015/decreto_8469.htm>. Acesso em: 29 set. 2016.

GRAMSCI, A. Cadernos do Cárcere. v. 4. Temas de cultura. Ação católica. Americanismo e fordismo. Rio de Janeiro: Civilização Brasileira, 2001.

HARVEY, D. O enigma do capital: e as crises do capitalismo. São Paulo: Boitempo, 2011.

HARVEY, D. O novo imperialismo. 2. ed. São Paulo: Loyola, 2005. 
HOLLAND, C. Mais uma escola é ocupada contra projeto de parceria público-privada. G1, Mato Grosso, jun. 2016. Seção Mato Grosso notícia. Disponível em: <http://g1.globo.com/matogrosso/noticia/2016/06/mais-2-escolas-sao-ocupadas-contra-projeto-de-parceria-publicoprivada.html>. Acesso em: 2 nov. 2016.

INEP. Instituto Nacional de Estudos e Pesquisas Educacionais Anísio Teixeira. Sinopse Estatística da Educação Básica 2015 [online]. Brasília: Inep, 2016. Disponível em: <http://portal.inep.gov.br/basica-censo-escolar-sinopse-sinopse>. Acesso em: 4 nov. 2016.

KLEIN, N. A doutrina do choque: a ascensão do capitalismo de desastre. Rio de Janeiro: Nova Fronteira, 2008.

KRAWCZYK, N. Charter school: uma escola pública que caminha e fala como escola privada. Carta Educação, maio 2016. Disponível em: < http://www.cartaeducacao.com.br/entrevistas/charterschool-uma-escola-publica-que-caminha-e-fala-como-escola-privada/>. Acesso em: 23 set. 2016.

LEHER, R. Não é só uma lógica econômica, é um horizonte para a formação humana no Brasil. [jul. 2016]. Entrevistador: C. Guimarães. Rio de Janeiro: Escola Politécnica de Saúde Joaquim Venâncio/Fundação Osvaldo Cruz. Entrevista concedida à EPSJV/Fiocruz. Disponível em: $<$ http://www.epsjv.fiocruz.br/noticias/entrevista/nao-e-so-uma-logica-economica-e-um-horizontepara-a-formacao-humana-no-brasil>. Acesso em: 2 nov. 2016.

LIS, L.; MARTELLO, A. Governo Temer anuncia concessão ou venda de 34 projetos de infraestrutura. G1, Brasília, set. 2016. Seção Economia. Disponível em: <http://g1.globo.com/economia/noticia/2016/09/governo-temer-anuncia-concessao-ou-venda-de25-projetos-de-infraestrutura.html>. Acesso em: 15 set. 2016.

MEAD, S.; MITCHEL, A. L.; ROTHERHAM, A. J. The state of charter school movement. Bellwether Education Partners, set. 2015. Disponível em: <http://bellwethereducation.org/sites/default/files/Charter\%20Research\%200908\%20FINAL.pdf >. Acesso em: 22 set. 2016.

MÉSZÁROS, I. Para além do capital: rumo a uma teoria de transição. São Paulo: Boitempo, 2002.

MOTTA, V. C. Ideologia do capital social: atribuindo uma face mais humana ao capital. Rio de Janeiro: EDUERJ/FAPERJ, 2012.

MUNGAL, A. S. Teach for America, Relay Graduate School and the Charter School Networks: The making of a parallel education structure. Education Policy Analysis Archive, Arizona, v. 24, n. 17, p. 1-30, fev. 2016.

RAVITCH, D. The Bloomberg reforms: an assessment. Diane Ravitch's blog. 2013. Disponível em: <https://dianeravitch.net/2013/11/04/the-bloomberg-reforms-an-assessment/>. Acesso em: 25 set. 2016. 
ROBERTSON, W. B. Mapping the profit motive: the distinct geography and demography of forprofit charter schools. Education Policy Analysis Archive, Arizona, v. 23, n. 69, p. 1-27, jul. 2015.

SAADI, R. Quem são as 4 OSs classificadas ontem? Medium. 2016. Disponível em: <https://medium.com/@rafaelsaddi/quem-s\%C3\%A3o-as-04-oss-classificadas-ontem95b8c89deb3c\#.kmlj6boqq $>$. Acesso em: 2 nov. 2016.

SARDINHA, R. O Projeto Procentro e as escolas charter: investigação de um modelo educacional defendido pela Fundação Itaú Social. 2013. 137 f. Dissertação (Mestrado em Educação) - Universidade Federal do Rio de Janeiro, Rio de Janeiro, 2013.

SCHÜLER, F. O tabu da escola estatal. Revista Época [online], mar. 2015. Seção Ideias. Disponível em: <http://epoca.globo.com/ideias/noticia/2015/03/o-tabu-da-bescola-estatalb.html>. Acesso em: 22 set. 2016.

SEDUC-MT. Secretaria de Estado da Educação - Mato Grosso. Edital de PMI: procedimento de manifestação de interesse no 001/2016 - PMI-SEDUC/MT, 14 de abril de 2016. Cuiabá, 2016. Disponível em: <http://media.wix.com/ugd/04b0f8_72991b872ffb4d3c8d021340e1caa196.pdf>. Acesso em: 2 nov. 2016.

SEDUCE-GO. Secretaria de Educação, Cultura e Esporte de Goiás. Raquel Teixeira dá detalhes sobre novo edital das OSs. SEDUCE, Mato Grosso, jun. 2016. Disponível em: <http://portal.seduc.go.gov.br/SitePages/Noticia.aspx?idNoticia=2010>. Acesso em: 2 nov. 2016.

SINTEP-MT. Sindicato dos Trabalhadores do Ensino Púbico de Mato Grosso. Resoluções da Assembleia Geral do Sindicato dos Trabalhadores do Ensino Público de Mato Grosso do dia 23 maio 2016. 2016. Disponível em: <https://drive.google.com/file/d/0Bx8Kty7SntbvMmdBYzZ4TGZ1RmM/view>. Acesso em: 2 nov. 2016.

VITOR, F. Estado deve implantar OSs na área da educação aos moldes das charter schools americanas. Jornal Opção [online], jan. 2015. Seção Cultural. Disponível em: $<$ http://www.jornalopcao.com.br/reportagens/estado-deve-implantar-oss-na-area-da-educacao-aosmoldes-das-charter-schools-americanas-2-25931/>. Acesso em: 28 set. 2016.

WOODWORTH, J. L.; RAYMOND, M. E. Charter school: growth and replication, vol. II. CREDO, $2013 . \quad$ Disponível em: <https://credo.stanford.edu/pdfs/CGAR\%20Growth\%20Volume\%20II.pdf>. Acesso em: 24 set. 2016.

Recebido em 14/11/2016

Versão corrigida recebida em 02/02/2017

Aceito em 12/02/2017

Práxis Educativa, Ponta Grossa, v. 12, n. 3, p. 728-748, set./dez. 2017 Disponível em: <http://www.revistas2.uepg.br/index.php/praxiseducativa $>$ 